\title{
Youth preferences for cigar brands: rates of use and characteristics of users
}

\author{
S Soldz, D J Huyser, E Dorsey
}

Tobacco Control 2003;12:155-160

See end of article for authors' affiliations

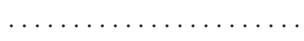

Correspondence to: Stephen Soldz, Boston Graduate School of Psychoanalysis, 1581 Beacon Street, Brookline, MA, 02446, USA; ssoldz@bgsp.edu

Received 10 August 2002. Accepted 4 March 2003

\begin{abstract}
Objective: Youth use of cigars has increased in the USA. Understanding brand preference among youth could help explain the attraction to cigars, and develop prevention strategies. This study reports on youth characteristics associated with preferences for cigar brands.

Design: Data are presented on 5006 students in grades 7-12 (ages 12-18 years) in classrooms administered the cigar use reasons evaluation (CURE), a questionnaire assessing alternative tobacco use (cigars, bidis, and kreteks).

Setting: Twelve middle and high schools across Massachusetts.

Main outcome measures: Preferred brands of cigars.

Results: Cigar smoking was reported by $16.4 \%$ of the sample. The brands preferred by over $5 \%$ of cigar users were Phillies (overall prevalence: $31.0 \%$, 95\% confidence interval (Cl) $27.9 \%$ to $34.3 \%$ ), Black \& Mild (12.3\%, 95\% Cl 9.8\% to $15.4 \%)$, Garcia y Vega $(11.4 \%, 95 \% \mathrm{Cl} 9.3 \%$ to $13.8 \%)$, Swisher Sweets $(9.6 \%$, 95\% Cl 7.6\% to $12.2 \%)$, Backwoods (6.1\%, 95\% Cl $4.6 \%$ to $8.1 \%)$, and nonlisted brands (16.4\%, $95 \% \mathrm{Cl} 14.0 \%$ to $19.0 \%)$. Male cigar smokers were significantly more likely than females to prefer five brands: Backwoods, Dutch Masters, Garcia y Vega, Phillies, and Swisher Sweets, while females were more likely to prefer Black \& Mild and non-listed brands. Brand preferences were also distinguished by self, friends' and siblings' tobacco use, race/ethnicity, parents' education and cigar use, GPA (grade point average), college plans, and community type. Urban students were more likely to prefer Black \& Mild; students whose parents smoke cigars preferred non-listed brands. Conclusions: Youth prefer certain brands, most notably Phillies. Particular brands are preferred by particular youth subgroups, raising the possibility of selective marketing toward these groups.
\end{abstract}

$A^{\prime}$ cigar use in the USA rose in the 1990s after a 20 year decline, demonstrating a $47.3 \%$ increase in the number of cigars consumed from 1993 to 1997, ${ }^{1}$ public health professionals become aware of cigar use by youth. ${ }^{23}$ For example, the 1999 National Youth Tobacco Survey reported lifetime rates of cigar use of $18.9 \%$ among middle school students and $41.6 \%$ among high school students; current (past month) cigar prevalence rates were $6.1 \%$ for middle school students and $15.3 \%$ for high school students, ${ }^{4}$ while rates of current cigar use reported in New Jersey were even higher. ${ }^{3}$ In some states, including Massachusetts, youth cigar smoking rates have declined in recent years, ${ }^{5}$ though national trends are less clear. ${ }^{6-9}$ These high rates of youth cigar use are of concern, both because cigar smoking poses serious health risks (for example, increased rates of oral, laryngeal, oesophageal, lung, and bladder cancers ${ }^{10-13}$ as well as heart and pulmonary disease $^{14}{ }^{15}$ ) and because cigar use may constitute a distinct pathway for exposure to nicotine among some youths with the potential for addiction.

Since youth cigar use has recently come to attention, little is known about who is smoking cigars and what brands they are choosing. In a focus group study of youth cigar use, the Office of the Inspector General of the US Department of Health and Human Services ${ }^{16}$ reported that brands mentioned by their respondents as being popular among youth included Swisher Sweets, Black \& Mild, and Phillies Blunts. Data on cigar brand preference among youth serves three purposes. First, it can be of help in understanding the attractions of cigars to youth in general and to particular subgroups of youth in particular. Second, these data can be of benefit in developing targeted prevention strategies to discourage and reduce youth cigar use. Finally, data on brand preference raise the possibility that certain companies may be deliberately targeting subgroups of youth, despite the fact that youth use of cigars is illegal. Thus, data that youth in general, or certain subgroups of youth in particular, prefer certain brands suggests that researchers and tobacco control policy makers should take a close look at the marketing strategies of the companies manufacturing and promoting those brands, to determine whether these companies are deliberately targeting youth.

Most of the knowledge available on cigar marketing strategies suggests that cigars are being promoted as an aspect of a successful lifestyle, through articles in the popular press and cigar specific magazines, ${ }^{17-19}$ rather than through promotions of individual brands. Identification of particular brands preferred by youth, especially if these brands differ from those used by the population at large, may suggest the possibility of brand specific marketing strategies aimed at youth. While brand preference cannot prove the existence of such marketing strategies, it can suggest which brands ought to be examined.

The current paper is part of the cigar use reasons evaluation (CURE) study, a school based survey of youth use of alternative tobacco products-cigars, bidis, and kreteks (clove cigarettes). This paper presents quantitative data on youth preference for different cigar brands and characteristics of youth cigar smokers who prefer particular brands. The CURE contains items assessing respondent preference for many common cigar brands, including most brands mentioned in focus groups as being used by youth, and those observed frequently in pharmacies and tobacco shops. Presented here are rates of use among cigar smokers for each brand and univariate and multivariate examinations of the relations of these rates to characteristics of users, including demographics, school functioning, current use of cigarettes and blunts, and smoking of cigars and cigarettes by parents, siblings, and friends. 
Table 1 Rates of expressed preference for cigar brands (cigar users only)

\begin{tabular}{|c|c|c|c|c|c|}
\hline \multirow[b]{3}{*}{ Cigar brands } & \multirow[b]{2}{*}{ Total } & \multicolumn{2}{|l|}{ Sex } & \multicolumn{2}{|l|}{ School level } \\
\hline & & Male & Female & Middle & High \\
\hline & $\begin{array}{l}\%(95 \% \mathrm{Cl}) \\
(\mathrm{n}=819)\end{array}$ & $\begin{array}{l}\%(95 \% \mathrm{Cl}) \\
(\mathrm{n}=586)\end{array}$ & $\begin{array}{l}\%(95 \% \mathrm{Cl}) \\
(\mathrm{n}=233)\end{array}$ & $\begin{array}{l}\%(95 \% \mathrm{Cl}) \\
(\mathrm{n}=188)\end{array}$ & $\begin{array}{l}\%(95 \% \mathrm{Cl}) \\
(\mathrm{n}=631)\end{array}$ \\
\hline Backwoods & 6.1 & $\begin{array}{l}7.3 \\
(5.4 \text { to } 9.9)\end{array}$ & $3.0^{*}$ & $\begin{array}{l}8.5 \\
(5.3 \text { to } 13.5)\end{array}$ & $\begin{array}{l}5.4 \\
(3.8 \text { to } 7.6)\end{array}$ \\
\hline Black Dutchess & 2.0 & 1.5 & 3.0 & 3.2 & 1.6 \\
\hline Black \& Mild & $\begin{array}{l}12.3 \\
(9.8 \text { to } 15.4)\end{array}$ & $\begin{array}{l}10.8 \\
(8.3 \text { to } 13.9)\end{array}$ & $\begin{array}{l}16.3^{*} \\
(11.5 \text { to } 22.6)\end{array}$ & $\begin{array}{l}20.2 \\
(14.0 \text { to } 28.3)\end{array}$ & $\begin{array}{l}10.0^{* *} \\
(7.4 \text { to } 13.3)\end{array}$ \\
\hline Dannemann & $\begin{array}{l}0.7 \\
(0.3 \text { to } 1.6)\end{array}$ & $\begin{array}{l}0.7 \\
(0.3 \text { to } 1.8)\end{array}$ & $\begin{array}{l}0.9 \\
(0.2 \text { to } 3.4)\end{array}$ & $\begin{array}{l}1.6 \\
(0.5 \text { to } 4.7)\end{array}$ & $\begin{array}{l}0.5 \\
(0.2 \text { to } 1.5)\end{array}$ \\
\hline Dutch Masters & $\begin{array}{l}3.7 \\
(2.6 \text { to } 5.1)\end{array}$ & $\begin{array}{l}4.6 \\
(3.2 \text { to } 6.6)\end{array}$ & $\begin{array}{l}1.3^{*} \\
(0.4 \text { to } 3.9)\end{array}$ & $\begin{array}{l}4.8 \\
(2.6 \text { to } 8.5)\end{array}$ & $\begin{array}{l}3.3 \\
(2.2 \text { to } 5.0)\end{array}$ \\
\hline Garcia y Vega & $\begin{array}{l}11.4 \\
(9.3 \text { to } 13.8)\end{array}$ & $\begin{array}{l}13.0 \\
(10.3 \text { to } 16.1)\end{array}$ & $\begin{array}{l}7.3^{*} \\
(4.6 \text { to } 11.5)\end{array}$ & $\begin{array}{l}6.9 \\
(3.9 \text { to } 12.0)\end{array}$ & $\begin{array}{l}12.7^{*} \\
(10.2 \text { to } 15.7)\end{array}$ \\
\hline King Edward & $\begin{array}{l}2.6 \\
(1.6 \text { to } 4.0)\end{array}$ & $\begin{array}{l}2.7 \\
(1.7 \text { to } 4.5)\end{array}$ & $\begin{array}{l}2.1 \\
(0.9 \text { to } 5.1)\end{array}$ & $\begin{array}{l}2.7 \\
(1.1 \text { to } 6.2)\end{array}$ & $\begin{array}{l}2.5 \\
(1.5 \text { to } 4.2)\end{array}$ \\
\hline Parodi & $\begin{array}{l}0.7 \\
(0.3 \text { to } 1.8)\end{array}$ & $\begin{array}{l}0.7 \\
(0.3 \text { to } 1.8)\end{array}$ & $\begin{array}{l}0.9 \\
(0.2 \text { to } 3.4)\end{array}$ & $\begin{array}{l}0.5 \\
(0.1 \text { to } 3.8)\end{array}$ & $\begin{array}{l}0.8 \\
(0.3 \text { to } 2.2)\end{array}$ \\
\hline Phillies & $\begin{array}{l}31.0 \\
(27.9 \text { to } 34.3)\end{array}$ & $\begin{array}{l}34.5 \\
(30.4 \text { to } 38.8)\end{array}$ & $\begin{array}{l}22.3^{* *} \\
(17.4 \text { to } 28.2)\end{array}$ & $\begin{array}{l}27.7 \\
(21.7 \text { to } 34.6)\end{array}$ & $\begin{array}{l}32.0 \\
(28.4 \text { to } 35.8)\end{array}$ \\
\hline Prince Albert & $\begin{array}{l}2.2 \\
(1.4 \text { to } 3.4)\end{array}$ & $\begin{array}{l}1.9 \\
(1.1 \text { to } 3.3 \text { ) }\end{array}$ & $\begin{array}{l}3.0 \\
(1.5 \text { to } 6.1)\end{array}$ & $\begin{array}{l}0.0 \\
-\end{array}$ & $\begin{array}{l}2.9^{*} \\
(1.9 \text { to } 4.3)\end{array}$ \\
\hline Robert Burns & $\begin{array}{l}0.5 \\
(0.2 \text { to } 1.3)\end{array}$ & $\begin{array}{l}0.5 \\
(0.2 \text { to } 1.6)\end{array}$ & $\begin{array}{l}0.4 \\
(0.1 \text { to } 3.0)\end{array}$ & $\begin{array}{l}1.1 \\
(0.3 \text { to } 4.1)\end{array}$ & $\begin{array}{l}0.3 \\
(0.1 \text { to } 1.3)\end{array}$ \\
\hline Swisher Sweets & $\begin{array}{l}9.6 \\
(7.6 \text { to } 12.2)\end{array}$ & $\begin{array}{l}11.9 \\
(9.4 \text { to } 15.1)\end{array}$ & $\begin{array}{l}3.9 * * \\
(1.9 \text { to } 7.7)\end{array}$ & $\begin{array}{l}5.3 \\
(2.8 \text { to } 9.8)\end{array}$ & $\begin{array}{l}10.9^{*} \\
(8.4 \text { to } 14.0 \text { ) }\end{array}$ \\
\hline White Owl & $\begin{array}{l}3.7 \\
(2.6 \text { to } 5.2)\end{array}$ & $\begin{array}{l}3.6 \\
(2.3 \text { to } 5.5)\end{array}$ & $\begin{array}{l}3.9 \\
(2.0 \text { to } 7.2)\end{array}$ & $\begin{array}{l}4.8 \\
(2.5 \text { to } 8.9)\end{array}$ & $\begin{array}{l}3.3 \\
(2.2 \text { to } 5.0)\end{array}$ \\
\hline Non-listed & $\begin{array}{l}16.4 \\
(14.0 \text { to } 19.0)\end{array}$ & $\begin{array}{l}14.7 \\
(12.1 \text { to } 17.6)\end{array}$ & $\begin{array}{l}20.6^{*} \\
(15.5 \text { to } 26.8)\end{array}$ & $\begin{array}{l}11.2 \\
(7.6 \text { to } 16.1)\end{array}$ & $\begin{array}{l}17.9^{*} \\
(15.2 \text { to } 21.0)\end{array}$ \\
\hline
\end{tabular}

\section{METHODS \\ Participants}

The CURE was administered to 5297 students in grades 6-12 (ages 11-18 years) in 12 schools across Massachusetts. These schools included 11 public schools and one urban parochial school. The schools were a convenience sample of those willing to participate in exchange for receiving feedback on the prevalence of tobacco and other substance use in their school. While a random sample would have been desirable, limited resources precluded obtaining such a sample. Nonetheless, the schools were broadly distributed across the state in terms of geography, type of community, and scores on the Massachusetts Comprehensive Assessment System standardised achievement tests.

Because only four of 281 students in grade 6 reported lifetime cigar use, the sixth graders were not included in further analyses. A further 10 students did not respond to the cigar brand questions, thus leaving 5006 respondents. Of the remaining students, $819(16.4 \%)$ did not endorse the option "I never smoke cigars or cigarillos" for the question on cigar brands and were classified as cigar smokers. Brand preferences are reported for these 819 students. This group was $71.6 \%$ male, $77.0 \%$ high school, $83.6 \%$ white, $2.0 \%$ black, $6.7 \%$ Hispanic, 2.6\% Asian/Pacific Islander, 5.2\% other race/ ethnicity. These rates can be compared with the school year 2000 statewide public school race/ethnicity breakdown of 76.7\% white, $8.6 \%$ black, $10.2 \%$ Hispanic, $4.3 \%$ Asian/Pacific Islander, and $0.3 \%$ other; the CURE sample was thus more white and less black and Hispanic than was true state wide. The grade distribution was weighted towards grades 8 (23.2\% $v 18.2 \%$ statewide in 1999$)$ and $9(23.5 \% v 18.5 \%$ state wide), with an under representation of both seventh (16.4\% v 18.2\%) and 12 th graders $(8.1 \% v$ to $13.7 \%)$.

\section{CURE survey}

From the CURE survey we used items on cigar brand preference with the stem: "If you smoke cigars, cigarillos, or little cigars, what brand do you usually smoke (NOT as a blunt)". Based on pilot data, multiple responses were allowed. Among cigar smokers, 9.2\% reported preferences for multiple brands.

Brands listed were: Backwoods, Black Dutchess, Black \& Mild, Dannemann, Dutch Masters, Garcia y Vega, King Edward, Parodi, Phillies, Prince Albert, Robert Burns, Swisher Sweets, White Owl, and other (referred to here as non-listed brands). These brands were selected based on visits to pharmacies and tobacco shops, complemented by youth focus groups and pilot survey administrations. It should be kept in mind that many of these brands include a number of separate products, often covering several distinct types of cigars-for example, blunts, cigarillos, sweets, etc. For example, Swisher Sweets markets at least five distinct types of cigars: Slims, Natural, Cigarillos, Blunts, and Little Cigars.

One methodological complexity of research on youth cigar use is that many youths are using cigars to smoke marijuana. Blunts, as cigars used this way are called, are formed by hollowing out the cigar and filling it with marijuana. One result of the practice of blunting is that, in prior surveys, it has been impossible to tell whether youth self reports of cigar use were actually referring to use of cigars as a tobacco product or of blunts as a drug delivery device. ${ }^{16}$ The CURE study made extensive efforts to try to distinguish cigar use from the use of 
Table 2 Univariate predictors of cigar brand preference

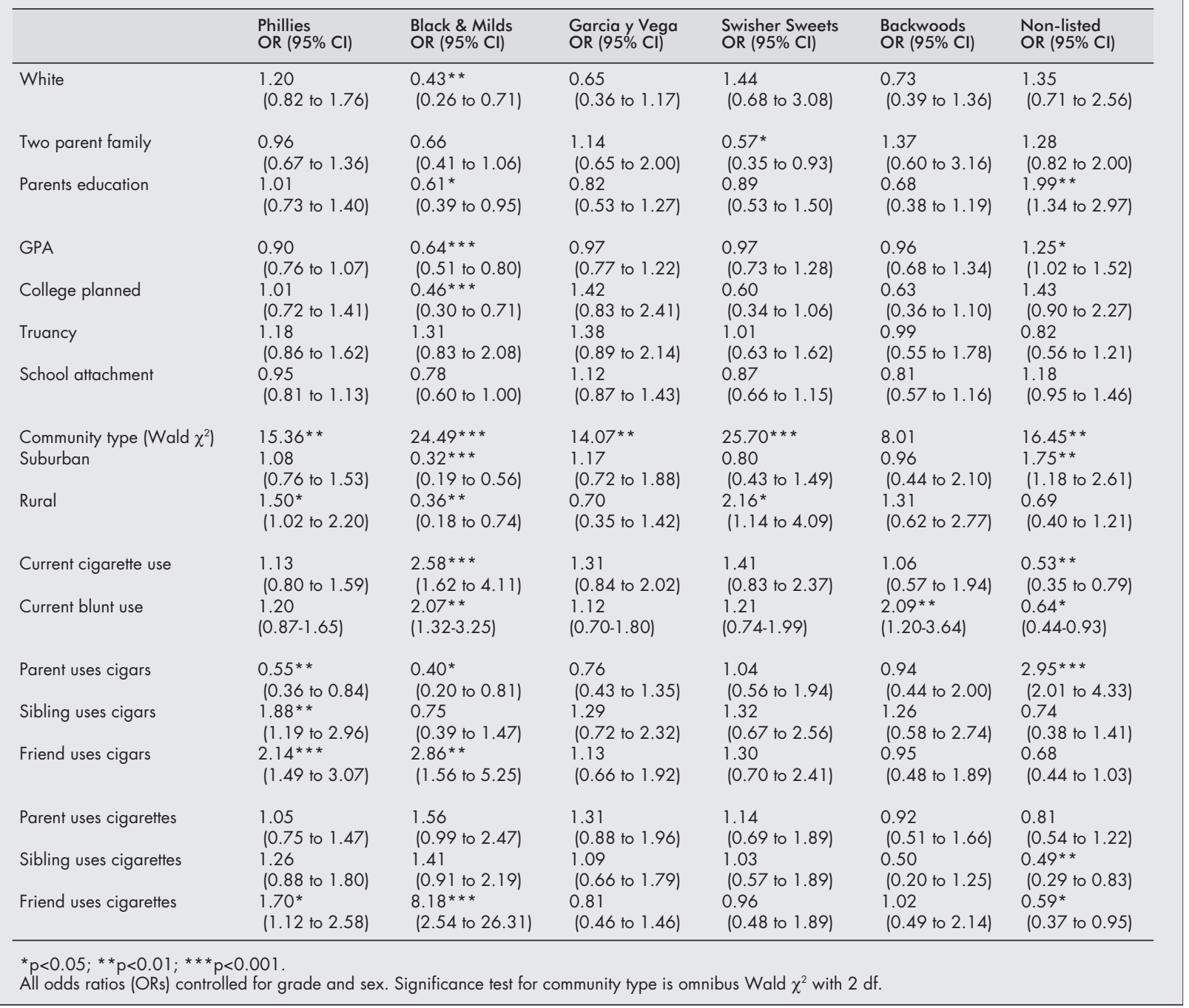

cigars as a marijuana delivery device (blunt use). For example, the term "blunts" was defined for respondents as "cigars filled with marijuana (grass, pot weed, reefer)", and respondents were asked about marijuana and blunt use, including the brands of cigars used for making blunts, before being asked about cigar use. Further, the CURE included explicit instructions in every cigar question emphasising that the question did not refer to the use of cigars as blunts. It should be clarified that the term "blunt" is also a term used for certain cigar products-for example, Phillies Blunts; focus groups and careful examination of completed surveys suggested that respondents were able to distinguish between these two uses of the term.

Other variables from the CURE used in the current analyses include sex, race/ethnicity (coded as white/non-white because of the extremely small cell sizes when the non-white category was further subdivided), type of community (urban, suburban, rural), whether either parent had graduated from college, family structure (whether the youth lived with two parents), self reported grade point average (GPA), truancy, school attachment (a single item assessing respondent liking of school), plans to attend college, whether the respondent was a current user of cigarettes or blunts, and dichotomous variables assessing use of cigarettes or cigars by parents, siblings, or close friends.

\section{Procedure}

Schools were recruited by contacting health coordinators and other school personnel offering school prevalence data in exchange for participation. To reduce selection bias, participating schools agreed to administer the CURE in classes that were required of all students, usually health or physical education classes. One result was that the sample was skewed toward grades (namely grades 8 and 9) where such classes are often required. The CURE was administered by teachers following a script provided to them.

\section{Data analysis}

Analyses consist of rates of use of each brand among cigar smokers overall and by sex and middle versus high school. Univariate logistic regression models examined the relation between user characteristics and use of the most prevalent brands, controlling for sex and grade, and multivariate logistic regression predicted use of each common brand from all characteristics which had univariate associations with at least one of the most frequently used brands. We present both univariate and multivariate analyses because the former are useful in identifying which groups of youth are smoking particular brands; the univariate analyses can aid in the design of prevention activities, whereas the multivariate analyses are often more useful in suggesting possible causation. In order to adjust for the lack of independence of students nested in 
Table 3 Multivariate predictors of cigar brand preference

\begin{tabular}{|c|c|c|c|c|c|c|}
\hline & $\begin{array}{l}\text { Phillies } \\
\text { OR ( } 95 \% \mathrm{Cl})\end{array}$ & $\begin{array}{l}\text { Black \& Milds } \\
\text { OR }(95 \% \text { Cl) }\end{array}$ & $\begin{array}{l}\text { Garcia y Vega } \\
\text { OR }(95 \% \text { CI) }\end{array}$ & $\begin{array}{l}\text { Swisher Sweets } \\
\text { OR }(95 \% \text { Cl) }\end{array}$ & $\begin{array}{l}\text { Backwoods } \\
\text { OR }(95 \% \mathrm{Cl})\end{array}$ & $\begin{array}{l}\text { Non-listed } \\
\text { OR }(95 \% \mathrm{Cl})\end{array}$ \\
\hline Sex (female) & $\begin{array}{l}0.55^{* *} \\
(0.36 \text { to } 0.83)\end{array}$ & $\begin{array}{l}1.26 \\
(0.73 \text { to } 2.20)\end{array}$ & $\begin{array}{l}0.56 \\
(0.29 \text { to } 1.06)\end{array}$ & $\begin{array}{l}0.32^{* *} \\
(0.14 \text { to } 0.71)\end{array}$ & $\begin{array}{l}0.39 \\
(0.14 \text { to } 1.09)\end{array}$ & $\begin{array}{l}1.83^{*} \\
(1.11 \text { to } 3.03)\end{array}$ \\
\hline Grade & $\begin{array}{l}0.99 \\
(0.88 \text { to } 1.11)\end{array}$ & $\begin{array}{l}0.92 \\
(0.78 \text { to } 1.09)\end{array}$ & $\begin{array}{l}1.23^{*} \\
(1.04 \text { to } 1.46)\end{array}$ & $\begin{array}{l}1.23^{*} \\
(1.02 \text { to } 1.49)\end{array}$ & $\begin{array}{l}0.88 \\
(0.71 \text { to } 1.09)\end{array}$ & $\begin{array}{l}1.06 \\
(0.93 \text { to } 1.21)\end{array}$ \\
\hline White & $\begin{array}{l}1.33 \\
(0.83 \text { to } 2.12)\end{array}$ & $\begin{array}{l}0.96 \\
(0.48 \text { to } 1.92)\end{array}$ & $\begin{array}{l}0.64 \\
(0.35 \text { to } 1.19)\end{array}$ & $\begin{array}{l}1.20 \\
(0.53 \text { to } 2.71)\end{array}$ & $\begin{array}{l}0.89 \\
(0.40 \text { to } 1.98)\end{array}$ & $\begin{array}{l}1.08 \\
(0.54 \text { to } 2.14)\end{array}$ \\
\hline Two parent family & $\begin{array}{l}1.06 \\
(0.71 \text { to } 1.57)\end{array}$ & $\begin{array}{l}1.07 \\
(0.61 \text { to } 1.85)\end{array}$ & $\begin{array}{l}1.43 \\
(0.76 \text { to } 2.72)\end{array}$ & $\begin{array}{l}0.51^{*} \\
(0.29 \text { to } 0.91)\end{array}$ & $\begin{array}{l}1.40 \\
(0.54 \text { to } 3.62)\end{array}$ & $\begin{array}{l}1.02 \\
(0.60 \text { to } 1.72)\end{array}$ \\
\hline Parents education & $\begin{array}{l}1.05 \\
(0.73 \text { to } 1.49)\end{array}$ & $\begin{array}{l}0.77 \\
(0.46 \text { to } 1.29)\end{array}$ & $\begin{array}{l}0.79 \\
(0.48 \text { to } 1.31)\end{array}$ & $\begin{array}{l}0.91 \\
(0.52 \text { to } 1.61)\end{array}$ & $\begin{array}{l}0.71 \\
(0.39 \text { to } 1.28)\end{array}$ & $\begin{array}{l}1.82 * * \\
(1.16 \text { to } 2.83)\end{array}$ \\
\hline GPA & $\begin{array}{l}0.95 \\
(0.78 \text { to } 1.15)\end{array}$ & $\begin{array}{l}0.76 \\
(0.55 \text { to } 1.03)\end{array}$ & $\begin{array}{l}0.92 \\
(0.70 \text { to } 1.20)\end{array}$ & $\begin{array}{l}1.25 \\
(0.91 \text { to } 1.73)\end{array}$ & $\begin{array}{l}1.18 \\
(0.80 \text { to } 1.73)\end{array}$ & $\begin{array}{l}0.96 \\
(0.74 \text { to } 1.25)\end{array}$ \\
\hline College plans & $\begin{array}{l}1.19 \\
(0.79 \text { to } 1.79)\end{array}$ & $\begin{array}{l}0.67 \\
(0.39 \text { to } 1.16)\end{array}$ & $\begin{array}{l}1.64 \\
(0.83 \text { to } 3.24)\end{array}$ & $\begin{array}{l}0.72 \\
(0.39 \text { to } 1.33)\end{array}$ & $\begin{array}{l}0.55 \\
(0.29 \text { to } 1.06)\end{array}$ & $\begin{array}{l}0.88 \\
(0.51 \text { to } 1.51)\end{array}$ \\
\hline Community type (Wald $\chi^{2}$ ) & 4.33 & $11.84 * *$ & 1.22 & 4.39 & 0.95 & $9.65^{* *}$ \\
\hline Suburban & $\begin{array}{l}1.25 \\
(0.86 \text { to } 1.82)\end{array}$ & $\begin{array}{l}0.33^{* *} \\
(0.17 \text { to } 0.64)\end{array}$ & $\begin{array}{l}1.19 \\
(0.70 \text { to } 2.01)\end{array}$ & $\begin{array}{l}0.77 \\
(0.42 \text { to } 1.42)\end{array}$ & $\begin{array}{l}0.96 \\
(0.41 \text { to } 2.21)\end{array}$ & $\begin{array}{l}1.42 \\
(0.92 \text { to } 2.18)\end{array}$ \\
\hline Rural & $\begin{array}{l}1.60^{*} \\
(1.03 \text { to } 2.49)\end{array}$ & $\begin{array}{l}0.40^{*} \\
(0.18 \text { to } 0.88)\end{array}$ & $\begin{array}{l}0.79 \\
(0.37 \text { to } 1.68)\end{array}$ & $\begin{array}{l}1.67 \\
(0.83 \text { to } 3.36)\end{array}$ & $\begin{array}{l}1.41 \\
(0.63 \text { to } 3.13)\end{array}$ & $\begin{array}{l}0.51 \\
(0.25 \text { to } 1.01)\end{array}$ \\
\hline Current cigarette use & $\begin{array}{l}0.91 \\
(0.61 \text { to } 1.36)\end{array}$ & $\begin{array}{l}1.34 \\
(0.75 \text { to } 2.38)\end{array}$ & $\begin{array}{l}1.38 \\
(0.82 \text { to } 2.32 \text { ) }\end{array}$ & $\begin{array}{l}1.47 \\
(0.84 \text { to } 2.58)\end{array}$ & $\begin{array}{l}0.90 \\
(0.42 \text { to } 1.94)\end{array}$ & $\begin{array}{l}0.59 \\
(0.35 \text { to } 1.00)\end{array}$ \\
\hline Current blunt use & $\begin{array}{l}1.21 \\
(0.85 \text { to } 1.72)\end{array}$ & $\begin{array}{l}1.29 \\
(0.76 \text { to } 2.18)\end{array}$ & $\begin{array}{l}1.02 \\
(0.58 \text { to } 1.78)\end{array}$ & $\begin{array}{l}0.99 \\
(0.57 \text { to } 1.74)\end{array}$ & $\begin{array}{l}2.46 \\
(1.26 \text { to } 4.80)\end{array}$ & $\begin{array}{l}0.78 \\
(0.48 \text { to } 1.26)\end{array}$ \\
\hline Parent uses cigars & $\begin{array}{l}0.49^{* *} \\
(0.32 \text { to } 0.75)\end{array}$ & $\begin{array}{l}0.25^{* *} \\
(0.09 \text { to } 0.70)\end{array}$ & $\begin{array}{l}0.82 \\
(0.44 \text { to } 1.49)\end{array}$ & $\begin{array}{l}1.06 \\
(0.54 \text { to } 2.08)\end{array}$ & $\begin{array}{l}1.05 \\
(0.47 \text { to } 2.37)\end{array}$ & $\begin{array}{l}3.08^{* * *} \\
(2.00 \text { to } 4.72)\end{array}$ \\
\hline Sibling uses cigars & $\begin{array}{l}1.69^{*} \\
(1.01 \text { to } 2.85)\end{array}$ & $\begin{array}{l}0.86 \\
(0.41 \text { to } 1.77)\end{array}$ & $\begin{array}{l}1.17 \\
(0.62 \text { to } 2.18)\end{array}$ & $\begin{array}{l}1.14 \\
(0.47 \text { to } 2.76)\end{array}$ & $\begin{array}{l}2.13 \\
(0.77 \text { to } 5.87)\end{array}$ & $\begin{array}{l}0.99 \\
(0.49 \text { to } 1.98)\end{array}$ \\
\hline Friend uses cigars & $\begin{array}{l}1.87^{* *} \\
(1.24 \text { to } 2.82)\end{array}$ & $\begin{array}{l}1.87 \\
(0.92 \text { to } 3.82)\end{array}$ & $\begin{array}{l}1.23 \\
(0.69 \text { to } 2.20)\end{array}$ & $\begin{array}{l}1.57 \\
(0.78 \text { to } 3.16)\end{array}$ & $\begin{array}{l}0.77 \\
(0.35 \text { to } 1.70)\end{array}$ & $\begin{array}{l}0.75 \\
(0.45 \text { to } 1.25)\end{array}$ \\
\hline Sibling uses cigarettes & $\begin{array}{l}1.03 \\
(0.67 \text { to } 1.59)\end{array}$ & $\begin{array}{l}1.25 \\
(0.72 \text { to } 2.17)\end{array}$ & $\begin{array}{l}0.95 \\
(0.52 \text { to } 1.74)\end{array}$ & $\begin{array}{l}1.16 \\
(0.55 \text { to } 2.48)\end{array}$ & $\begin{array}{l}0.29 * \\
(0.08 \text { to } 0.99)\end{array}$ & $\begin{array}{l}0.49^{*} \\
(0.27 \text { to } 0.91)\end{array}$ \\
\hline Friends uses cigarettes & $\begin{array}{l}1.35 \\
(0.79 \text { to } 2.30)\end{array}$ & $\begin{array}{l}4.07 \\
(0.92 \text { to } 18.12)\end{array}$ & $\begin{array}{l}0.66 \\
(0.31 \text { to } 1.40)\end{array}$ & $\begin{array}{l}0.54 \\
(0.25 \text { to } 1.19)\end{array}$ & $\begin{array}{l}0.82 \\
(0.32 \text { to } 2.10)\end{array}$ & $\begin{array}{l}1.03 \\
(0.57 \text { to } 1.85)\end{array}$ \\
\hline Wald $\chi 2$ & 46.71 *** & $47.28 * * *$ & $30.68^{*}$ & 25.79 & $41.95^{* * *}$ & $70.06 * * *$ \\
\hline
\end{tabular}

classrooms, all confidence intervals and significance tests are based on the Huber-White robust variance estimator. ${ }^{20-22}$

\section{RESULTS}

\section{Rates of brand preference}

Table 1 reports the brands named by at least $5 \%$ of cigar smoking respondents. Male cigar smokers were significantly more likely than females to use five brands: Backwoods, Dutch Masters, Garcia y Vega, Phillies, and Swisher Sweets. Females were more likely to prefer Black \& Mild and non-listed brands. Middle school cigar users were more likely than high school users to smoke Black \& Mild, while high school smokers were more likely to use Garcia y Vega, Prince Albert, Swisher Sweets, and non-listed brands.

\section{Characteristics of youths preferring specific brands}

The brands preferred by at least $5 \%$ of cigar smokers were entered as the dependent variables in a series of univariate analyses assessing the relation between brand use and characteristics of users, controlling for sex and grade (table 2). For analyses involving type of community, a Wald $\chi^{2}$ with two degrees of freedom was used to assess the overall significance of the two dummy variables for suburban and rural communities before the significance of the specific coefficients was examined.
In the univariate analyses, Phillies were more likely to be preferred by rural cigar smokers and by those whose siblings or friends smoked cigars or cigarettes and less likely to be used by those whose parents smoked cigars. Black \& Milds were preferred by minority cigar smokers, those from urban communities, current cigarette and blunt users, and those whose friends smoked cigars or cigarettes. Black \& Milds were less likely to be used by cigar smokers with higher GPAs, those with plans to attend college, and those whose parents smoke cigars or who have graduated from college. Swisher Sweets were more likely to be smoked by cigar using youth from rural communities and less likely to be smoked by youth from two parent families. Backwoods were preferred by current blunt users. Non-listed cigar brands were preferred by cigar smoking youth from suburban communities, those with higher GPAs, and those with parents who were college graduates or who were themselves cigar smokers; these brands were used less by young cigar smokers who were also current cigarette or blunt smokers or whose friends or siblings smoked cigarettes. Three variables-truancy, school attachment, and parent's use of cigarettes-were not related to any brand preferences.

These univariate analyses were followed by a set of multivariate analyses with preference for each of the six most used brands as the dependent variable and all variables exhibiting a significant univariate association with at least one of these brands as the independent variables (table 3). Results of 
the multivariate analyses broadly paralleled the univariate analyses with all but two significant univariate effects in the same direction in the multivariate analyses, though in some instances the effects were no longer significant. Most notably, Black \& Milds were no longer significantly associated with minority status, GPA, parent's education, current cigarette or blunt use, the absence of college plans or friends' use of cigars and cigarettes. Use of non-listed brands was no longer significantly associated with attending a suburban school, GPA, current cigarette or blunt use, or friends' cigarette smoking.

\section{DISCUSSION}

These results indicate that certain brands are more likely to be used by adolescent cigar smokers. By far the most popular was Phillies, perhaps not coincidentally, the brand most likely to be used for blunting-hollowing out cigars and filling them with marijuana. In the CURE sample, $20.0 \%$ of respondents reported lifetime use of cigars for making blunts and $59.4 \%$ of those used Phillies for this purpose, though current blunt use was not related to a preference for Phillies when smoking cigars as cigars. As the CURE distinguished clearly between smoking of cigars for making blunts and as cigars, these results suggest that the popularity of Phillies is not due simply to their use as blunts containing marijuana.

Two other brands were preferred by over $10 \%$ of the current sample of youthful cigar smokers: Black \& Mild and Garcia y Vega, while Swisher Sweets was the brand used by $9.6 \%$ of the sample. Interpretation of these rates is complicated by the multiplicity of products being marketed under a single brand name. Phillies, Garcia y Vega, and Swisher Sweets, in particular, cover the gamut of types of cigars under a single brand name, with at least 20 different types of cigars sold under the Phillies label. Unfortunately, the current study did not examine the particular products in use by youth. Future efforts should examine whether youth preference for these brands is primarily due to a few of the products bearing these brand labels or is largely due to the number of products available under a single brand name. Further research is needed to examine possible brand loyalty generalising across particular products.

One possible explanation for these youth preferences for cigar brands is that they simply reflect rates of use in the population in general. Data are available on market share of cigar brands in 1996. ${ }^{1}$ There are eight brands included both in the current study and the market share data (Backwoodsmarket share 3.2\%, Dutch Masters-4.5\%, Garcia y Vega4.5\%, King Edward-3.4\%, Phillies-15.0\%, Robert Burns$2.8 \%$, Swisher Sweets-9.4\%, and White Owl-6.0\%). While market share and brand preference are separate constructs and the years of data collection differ, the confidence intervals in the current study for those eight brands provide a rough gauge to examine whether preference rates match market share. For five of the eight brands, the reported market share lies outside the $95 \%$ confidence interval obtained in the current study. For three of these brands (Backwoods, Garcia y Vega, and Phillies), the preference rate is greater than the market share, whereas for two brands (Robert Burns and White Owl), the preference rate is less than the market share. The greatest discrepancies are for Phillies and Garcia y Vega, where the preference rates are more than twice the market share. Thus, it seems plausible to conclude that, for these products at least, youth preference is not simply a reflection of market share.

The examination of the characteristics of users of the different brands indicated that particular brands are attractive to users with specific characteristics. Most notable are the higher preference rates for Black \& Mild by females, middle school students, minority youth attending urban schools, those youth with lower GPAs, and those without plans to attend college. The fact that many of these associations did not

\section{What this paper adds}

In recent years, American youth have been smoking cigars in surprising numbers. Lifetime prevalence rates of over $40 \%$ for high school students have been reported; yet virtually nothing is known about this use, beyond basic rates. This paper reports the brands preferred by cigar smoking youth, based on results of a school based survey. It demonstrates that the most popular brand is Phillies, followed by Black \& Mild, and Garcia y Vega. Brand preferences vary by characteristics of cigar smokers. These results provide a guide for tobacco control efforts and also suggest that the marketing strategies of those brands most preferred by youth should be examined to determine whether companies are targetting youth.

hold up in the multivariate model does not detract from their importance. It only suggests that many of these characteristics are associated with each other and with attending school in an urban community, which was strongly associated with use of Black \& Milds even in the multivariate model. Interestingly, Black \& Milds are not even listed in the 1996 market share data, ${ }^{1}$ suggesting that their popularity among youth is much greater than that in the population at large. The possibility arises that Black \& Mild cigars are being deliberately marketed toward urban minority youth. In a focus group with urban minority youth, conducted while developing the CURE, participants mentioned that Black \& Mild was the brand they saw the most. Another factor that may contribute to the popularity among this group of young people is that Black \& Milds are sold individually, at a price well below \$1, making them attractive to those with little money. In any case, the marketing practices of the manufacturer of Black \& Mild and of the other brands popular among youth, especially Phillies and Garcia y Vega, deserve serious scrutiny by public health advocates to determine whether these companies are engaging in deliberate marketing or other promotional activities to segments of the illegal youth market for cigars. Since most cigar promotional activity does not involve traditional advertising, ${ }^{1}$ but other types of activity such as product placement in music videos and promotion in lifestyle magazines, ${ }^{16} 181923$ the possibility that promotional activities for these products are aimed at youth will be difficult to examine. Even if the preferences exhibited here are not the result of deliberate cigar company marketing activities, an understanding of the factors that lead young people to prefer one brand of cigar over another could be important in developing effective prevention messages to reduce teen cigar use.

Non-listed cigar brands were preferred by females, suburban and high school students, those with higher GPAs and college educated parents, those who are not current cigarette or blunt users, and youth with a cigar smoking parent. This pattern suggests that these types of cigars may be appealing to those who are less likely to smoke cigarettes and may constitute an alternative pathway to tobacco exposure and potential nicotine dependence for some youths.

The positive association between parental cigar use and non-listed brands suggests a possible parental modelling role for these cigars and also suggests that the non-listed brands may largely consist of premium cigars ${ }^{24}$ that are not included in our brand list. This is in contrast to preference for Phillies and Black \& Mild, which were negatively related to parental cigar use, even in the multivariate models. The reason for this negative association is unclear, though the positive relation between use of these brands and friends and/or sibling cigar use suggests that different social influences are at play here; use of these brands may be more associated with rebellion against parents and a gravitation toward peer influence. These 
issues need to be clarified if effective strategies for preventing cigar use among youth are to be developed.

Like all studies, this one has limitations that should be kept in mind. First, as the participating schools were not chosen randomly, the sample is a convenience sample of youth in one state-Massachusetts. Thus caution should be taken when interpreting results. The findings may not apply to youth in other states, or even to all students in Massachusetts. Thus, replications with population based representative samples in different parts of the country are essential to improve our understanding of youth cigar use. Second, while the study examined brand preference, most of these brands include a number of distinct products, and the study did not obtain information on which particular products were preferred.

Nonetheless, the results of the present study indicate that there are systematic relations between youth characteristics and cigar brand preferences. It is essential that the nature of this relation be clarified if effective anti-cigar smoking strategies are to be developed by tobacco control advocates. It is also important that trends in cigar use behaviours among youth be carefully monitored in order to identify changing patterns of use that may require modification of tobacco control strategies.

\section{ACKNOWLEDGEMENTS}

We would like to thank Michael Blasnik for consultation regarding data management and analysis and to Milton Soldz for editorial assistance. This project was funded by a grant from the Massachusetts Tobacco Control Program. IRB approval was granted by the IRB at the Lemuel Shattuck Hospital, Boston, Massachusetts.

\section{Authors' affiliations}

*S Soldz, D J Huyser, *E Dorsey, Boston Graduate School of

Psychoanalysis, Brookline, Massachusetts, USA

*Also Social Science Research and Evaluation, Inc

\section{REFERENCES}

1 US Department of Health and Human Services. Cigars: health effects and trends. Bethesda, Maryland: National Institutes of Health, National Cancer Institute, 1998. (NCl Smoking and Tobacco Control Monograph 9, NIH Publication No 98-4302.)

2 Centers for Disease Control and Prevention. Cigar smoking among teenagers - United States, Massachusetts, and New York, 1996. MMWR Morb Mortal Wkly Rep 1997;46:433-40.

3 Delnevo CD, Pevzner ES, Steinberg MB, et al. Cigar use in New Jersey among adolescents and adults. Am J Public Health 2002;92:943-5.
4 Centers for Disease Control and Prevention. Tobacco use among middle and high school students - United States 1999. MMWR Morb Mortal Wkly Rep 2000;49:49-53

5 Soldz S, Clark TW, Stewart E, et al. Decreased youth tobacco use in Massachusetts 1996 to 1999: evidence of tobacco control effectiveness. Tobacco Control 2002;11 (suppl ii):ii 14-19.

6 Centers for Disease Control and Prevention. CDC surveillance summaries, MMWR youth risk behavior surveillance - United States, 2001. Atlanta, Georgia: Centers for Disease Control and Prevention, 2002.

7 Centers for Disease Control and Prevention. CDC surveillance summaries, MMWR youth risk behavior surveillance - United States, 1999. Atlanta, Georgia: Centers for Disease Control and Prevention, 2000.

8 Centers for Disease Control and Prevention. Youth tobacco surveillance - United States, 1998-1999. MMWR Morb Mortal Wkly Rep 2000;49: 1-94.

9 Centers for Disease Control and Prevention. Youth tobacco surveillance - United States, 2000. MMWR Morb Mortal Wkly Rep 2001:50(SSO4): 1-84.

10 Baker F, Ainsworth SR, Dye JT, et al. Health risks associated with cigar smoking. JAMA 2000;284:735-40

11 LaVecchia C, Bosetti C, Negri E, et al. Cigar smoking and cancers of the upper digestive tract. I Natl Cancer Inst 1998:90:1670.

12 US Department of Health and Human Services. The health consequences of smoking: cancer. A report of the Surgeon General, 1982. Bethesda, Maryland: Public Health Service, Office on Smoking and Health, 1982 (DHHS Publication No (PHS) 82-50179.)

13 Pitard A, Brennan P, Clavel J, et al. Cigar, pipe, and cigarette smoking and bladder cancer risk in European men. Cancer Causes Control 2001;12:551-6.

14 US Department of Health and Human Services. The health consequences of smoking: chronic obstructive lung disease. A report of the Surgeon General, 1984. Rockville, Maryland: Public Health Service, Office on Smoking and Health, 1984. (DHHS Publication No (PHS) 84-50205.)

15 Jacobs EJ, Thun M, Apicella LF. Cigar smoking and death from coronary heart disease in a prospective study of US men. Arch Intern Med 1999:159:2413-8.

16 US Department of Health and Human Services. Youth use of cigars: patterns of use and perceptions of risk. Washington, DC: US Departmen of Health and Human Services, Office of the Inspector General, 1999.

17 Falit JL. Cigar advertising: targeting "baby-boomers" and older adults. Tobacco Control 1997;6:240-2.

18 Wenger LD, Malone RE, George A, et al. Cigar magazines: using tobacco to sell a lifestyle. Tobacco Control 2001;10:279-84.

19 Wenger L, Malone R, Bero L. The cigar revival and the popular press: a content analysis, 1987-1997. Am J Public Health 2001;91:288-91.

20 Albert P. Longitudinal data analysis (repeated measures) in clinical trials. Stat Med 1999;18:1707-32.

21 Diggle PJ, Liang KY, Zeger SL. Analysis of longitudinal data. Oxford: Oxford University Press, 1994

22 White H. Maximum likelihood estimation of misspecified models. Econometrica 1982;50:1-25.

23 Shanken MR, ed. Cigar aficionado's world of cigars. Philadelphia, Pennsylvania: Courage Books, 1996

24 Resnick J. International connoisseur's guide to cigars. New York: Black Dog \& Leventhal Publishers, 1996. 